\title{
Reviewer Acknowledgements for Global Journal of Health Science, Vol. 11, No. 2
}

Global Journal of Health Science wishes to acknowledge the following individuals for their assistance with peer review of manuscripts for this issue. Their help and contributions in maintaining the quality of the journal are greatly appreciated.

Global Journal of Health Science is recruiting reviewers for the journal. If you are interested in becoming a reviewer, we welcome you to join us. Please find the application form and details at http://recruitment.ccsenet.org and e-mail the completed application form to gjhs@ccsenet.org.

\section{Reviewers for Volume 11, Number 2}

Althea Jane Gamble Blakey, University of Otago, New Zealand

Ama Pokuaa Fenny, University of Ghana, Ghana

Amy E Jetton, Middle Tennessee State University Murfreesboro, United States of America

António Calha, Polytechnic Institute of Portalegre, Portugal

Ayesha Johnson, University of South Florida, United States of America

David John Lindsay, James Cook University, Australia

David Otieno Odongo, Masinde Muliro University of Science and Technology, Kenya

David Richard Walwyn, University of Pretoria, South Africa

Emad Adel Shdaifat, Imam Abdulrahman Bin Faisal University, Saudi Arabia

Evangelia Mavrikaki, National \& Kapodistrian University of Athens, Greece

Farahnaz Amini, UCSI University, Malaysia

Fengsong Gao, The University of Queensland, Australia

France Ncube, Bindura University of Science Education, Zimbabwe

Francisco Rodenas Rigla, University of Valencia, Spain

Gavric Zivana, University Banja Luka, Bosnia and Herzegovina

Georgann Valerie Weissman, Capella University, United States of America

Hülya YARDIMCI, Ankara University, Turkey

Jason Tsai, Lincoln College, United Kingdom

Marcel Wullschleger, University of Bern, Switzerland

Meng Zhao, Texas A\&M University at Corpus Christi, United States of America

Misheck Dube, North West University, South Africa

Pi-Ming Yeh, Missouri Western State University, United States of America

Raywat Deonandan, University of Ottawa, Canada

Robert Sloan, Kagoshima University Graduate School of Medical and Dental Sciences, Japan

Samir Othman, Hawler Medical University, Iraq

Soon Soo Hoo, Royal North Shore Hospital, Australia

Thammanard Charernboon, Thammasat University, Thailand

Thanusin Saleeon, Mae Fah Lung University, Thailand 